\title{
Analysis on the Countermeasures to Improve the International Competitiveness of the Main Agricultural Products of Jilin Province
}

\author{
Fang Wang \\ Jilin Engineering Normal University, Changchun Jilin, 130011, China
}

Key words: Agricultural products of Jilin Province, International competitiveness, Promoting countermeasure.

\begin{abstract}
This paper starts from the general development situation of the agricultural products of Jilin Province to analyze the international competitiveness and existing problems of the main agricultural products, proposes specific measures to improve the international competitiveness of the main agriculture products in Jilin Province.
\end{abstract}

\section{The general development situation of the agricultural products in Jilin Province}

Jilin Province is a big agricultural province in our country, production base of national important agricultural products, the improvement of its international competitiveness of main agricultural products not only can further enlarge the agricultural products export share of Jilin Province, stimulate the growth of agricultural efficiency, farmers' income growth and the rural stability, but also can lay a solid foundation for its economic growth, the realization of the construction of new socialist countryside and the comprehensive construction of well-off society. From the current situation, the technological content of agricultural products in Jilin Province is low, just accounts for $46 \%$, there is a great gap to the developed countries' $80 \%$. But Jilin Province has advantageous geographical location, locating in the world's second biggest "golden corn belt", which even can be compared with the world's biggest American corn belt. But so far, the highest corn yield of Jilin Province is just $440 \mathrm{~kg}$, compared with the agriculturally advanced countries like America, Australia, Brazil, etc., the gap is very wide. The international competitiveness of agricultural products in Jilin Province is pretty weak, there is still a great gap between the developed countries.

\section{Analysis on the international competitiveness of agricultural products in Jilin Province}

\section{Production factors}

Advantageous land resource

Jilin Province is located in the middle of the Songliao Plain, with flat terrain, abundant black soil resource and fertile soil, being praised as one of the world's famous three "golden corn belts", also China's golden corn belt and big barn. From the land resource, firstly, its cultivated land is large, the cultivated land area of Jilin Province is $6,443,900 \mathrm{hm}^{2}$, accounts for $34.39 \%$ of the land area; secondly, most of the cultivated land is located in the plain area, which is suitable for mechanized farming; thirdly, it has many reserve resources, uncultivated land, barren mountain, slopes, with multiple ecological forms, widely distributed, suitable for developing all kinds of agriculture. The organic matter content of the topsoil is 3\% 6\%, the highest reaches over $15 \%$.

\section{Advantageous climatic conditions}

Jilin Province is Temperate Continental Monsoon Climate, suitable for the growth of corn, rice, bean and some other agricultural products. Jilin Province has long sunshine duration in summer, with plenty of rains, average annual precipitation is $400 \sim 800 \mathrm{ml}$, providing a good condition for the growth of corn, wheat and beans. The sunshine in Autumn is also abundant, annual sunshine duration is around 3,000 hours, day and night temperature difference is big, which provides a necessary condition for agricultural products to accumulate nutrition. 
High quality of agricultural products

Jilin Province is the major grain producing areas and marketable grain base of China. At present, the overall grain production capability of Jilin Province is basically stable at the level of 30 million tons, and the per capita grain yield, exchange amount, commodity rate has been No.1 in China for many years. Besides, relying on corn resources advantage, Jilin Province is also China's important stockbreeding production bases and animal products producing base, and has the trend of great-leap-forward development. In recent years, its marketing number of pig, cow, the feeding amount of poultry and meat, output of meat, egg and milk are all higher than the national average.

It is the advantageous land resource and climatic condition providing effective guarantee for the quality of the agricultural products in Jilin Province. The oil content of corn in Jilin Province is averagely higher $0.5 \%$ than other places, the content of protein and starch is also at a higher level in China, it is an important raw material for industrial material and feed, being favored by domestic and foreign factories and customers.

Big science and technology talent team

The number of scientists, engineers and undergraduates in Jilin Province is at the top level in China. Jilin Province greatly develops and pays attention on talent training, it owns all kinds of scientific and technological talents who understand production technology and modern agriculture management.

\section{Demand condition}

In recent years, Jilin Province in in the forefront of China in part of grain sector, especially its grain commodity rate, per capita grain possession and per capita meat ranks No.1. We can see that domestic demand for agricultural products of Jilin Province is great, it also accounts for a great ratio even on agricultural products export.

\section{Government}

The rapid development of the agricultural product market of Jilin Province is benefited from government support and guidance. In order to improve the initial processing facility condition of the agricultural product producing base, to increase effective supply, to improve the product quality and safety level, for the new difficulties of the corn processors, Jilin provincial government put forward that for corn processors who do have difficulties in production can defer payment of taxes according to the relevant provisions of the tax law. Government gives great supports to the development of its agricultural products from the aspects of policy, expenditure, tax deduction and green channels.

\section{Problems of the agricultural products of Jilin Province existing in the international competition}

The production and processing of the agricultural products in Jilin Province have entered a rapid development period, an important turning period for institutional innovation, structure upgrading,quality promotion. Though the agricultural products production and processing in Jilin Province already has a certain scale and formed a batch of competitive industries, part of products have some competitiveness in the domestic and overseas market, but compared with the province with developed production and processing, it still has a certain gap on the aspects of the integral level, total size and competitiveness.

\section{Low industrial scale level, weak enterprise competitiveness}

The unique natural resources and ecological resources are the basis and condition for developing agricultural product producing and processing in Jilin Province. Throughout the current existing producing and processing enterprises of agricultural products in Jilin Province, though there are several agricultural product producing and processing enterprises and groups with strong competitiveness in China, but because the entry threshold for agriculture producing and processing is low, the small sized enterprises still account for a big proportion. Compared with agricultural products producing and processing enterprises in the developed areas like Shandong Province, Liaoning Province and Guangdong Province, its processing technology is backward and with low 
management level and fierce market competition, it is hard t realize scale economies effect. Therefore, agricultural product producing and processing enterprises in Jilin Province appear state of low sale level, total quantity insufficiency, weak competition, slow development speed, which greatly constrained the development of the agricultural product producing and processing enterprises.

\section{The export production system of agricultural products has problems}

In Jilin Province, except for seldom major export enterprises like "Deda Chicken" "Haoyue Beef" "Dacheng Corn" have sound production system and perfect organizational structure, most of other enterprises have problems on the production system. Normal production system is "company + base + farmer + standard", while most enterprises cannot realize, but just simple situation of "purchase + processing + export". This makes the export agricultural products in Jilin Province has many uncertain factors, which cannot guarantee market supply steadily; it also cannot guarantee their own competition on the international market, lacking of comprehensive ability of predicting risk, preventing risk and resisting risk.

\section{Brand effect is poor}

The agricultural product brand in Jilin Province is very few, famous brand and well-known bran are much rarer, only few enterprises (such as Deda Chicken, Haoyue Beef, Dacheng Corn) created their own brand, pay attention to product quality, positively take part in international market competition. Most of the middle and small sized enterprises are scattered acquisition, the quality is hard to be controlled, it is also hard to create their own brands. This directly caused the low technology content of agricultural product export in Jilin Province, with many traditional products but few innovative products, the new product research and development ability and technology innovation ability is low, which cannot well adapt $t$ the diverse requirements of international market, it is obviously influenced by the international market fluctuations. Brand and quality factor constrained the international competitiveness of agricultural products in Jilin Province, its international market share is always low. For example, the value of ginseng in Jilin Province is much higher than that of Korean ginseng, because lack of own brand and not famous, that the price of Korean ginseng is much higher than ginseng of Jilin Province.

\section{The export structure of agricultural products is not reasonable, the import and export trade development level is low}

At present, among the total volume trade of export agricultural products of Jilin province, the ration of the three main categories of chicken, corn and corn deep processing accounts for three quarters, other agricultural products accounts for a small ratio. The development advantage of the export trade of Jilin Province is mainly expressed on labor resource, but this resource advantage does not be fully embodied in its foreign trade. Meanwhile, the technological advantage of Jilin Province is obvious, the uneven distribution of industrial structure seriously constrained the development of the foreign trade in Jilin province.

\section{Agricultural products of Jilin Province face more complicated and strict foreign trade environment}

The America, South Korea, Japan and European Union successively made and implemented relevant food safety law and pesticide residues licensing benchmark to improve the quality requirements on import agricultural products. Under the situation of rising exports to South Korea, the complicated and strict inspection procedure of the General Catalog of Plant Diseases and Insect Pests in South Korea certainly will hinder the export growth of agricultural products of Jilin Province. When various countries set trade barrier to maintain their own trade benefits, in order to restrict import share and protect its own agricultural products, Japan issued POSITIVE LIST specially, this is the most strict food safety and hygiene standard in the world. Influenced by the POSITIVE LIST, the agricultural products of Jilin Province will face a more complicated and strict international trade environment. 


\section{Measures to improve the international competitiveness of the agricultural products of Jilin Province}

\section{Create green brand}

At present, there are already some enterprises in Jilin Province created their own brand in the international market, but the number of this kind of enterprises is two small, the influence is not enough. Though "Dacheng Corn" in Changchun, Jilin Province is an international brand, but its international influence is limited. The black fungus and tricholoma matsutake of the Changbai mountain shall not just account for big domestic market share, but also should take a place in the international market. Under the general trend of economic integration to create international famous brand, to make agricultural product enterprises in Jilin province bigger, stronger and better, to change the enterprises from passive subordinates into the makers and implementer of trade rules. Brand effect can increase enterprises' enthusiasm to take part in the international market, it is the inevitable course to become transnational corporation. Therefore, we should make full use of the agricultural advantages and ecological environment $f$ Jilin Province to optimize the import and export commodity structure of agricultural products, mainly support the deep processing of agricultural products, research and develop a batch of international famous brands to improve the competitiveness of the distinctive agricultural products of Jilin Province.

\section{Focus on cultivating leading corporation of agricultural product export}

Leading enterprises are the body to create distinctive agricultural products brand, strengthen the cultivating and support on the leading enterprises of distinctive agricultural product producing and processing, focus on the support and cultivating of a batch of leading enterprises, encourage enterprises to develop and enlarge production chain through acquisition, to be listed, issue shares and other ways.

\section{Pay attention to the quality and safety management of agricultural products}

If Jilin Province wants to take a place in the international market, it must pay more attention to the quality and safety management of agricultural products, to establish self checking and controlling system, help enterprises to perfect their own supervision, provide enterprises with some technological support, to perfect the quality standard certification of agricultural products, to improve the comprehensive level of agricultural products of the whole province, to establish a good image and to improve market competitiveness.

\section{Strengthen technological innovation, extend product chain}

Technological innovation is one of the effective method to improve international competitiveness of agricultural products, therefore, encourage the tight cooperation between the leading enterprises and colleges and universities and scientific research institutions, to form the integrative productioneducation- research system, and through positively introducing in domestic and overseas advance agricultural product processing technology to develop new technology and products with proprietary intellectual property rights, to improve utilization level of resources, extend production chain, increase added value of products, final to realize scale agricultural products processing system.

\section{Widen sales channels and go to the international market}

Agricultural products in Jilin Province shall not be limited to export to surrounding Asian countries, but to develop wider market, to make products diversified, to get into the international economic trend, to highlight own advantages to explore more new market; to make corresponding reform for the market system that suitable for the agriculture development of Jilin Province, to establish perfect system in the future international market, analyze specific issues, strengthen enterprises' developing force and resilience, gradually developed in the international agricultural products competition.

\section{Perfect the financing service system, decrease enterprise tax}

Perfecting the financing service system of agricultural product producing and processing enterprises needs to innovate the financing service system of agricultural product producing and processing enterprises. For the situation that there are many agricultural product producing and processing enterprises with small scale in Jilin Province, bank and other financing organizations should continue 
to perfect financial supply system and financial service, guarantee the enterprises' fund demand in many ways and with many methods. In addition, credit guaranty institution should outbreak the mode of mortgage loan through perfecting security guarantees to innovate financial service products, set professional microfinance department for middle and small sized enterprises to guarantee the smooth of the financial channels of agricultural product producing and processing enterprises. At the same time, Jilin provincial government and local government should make reasonable financial tax policy according to the real situation of agricultural products producing and processing enterprises to lower its production risks.

\section{Acknowledgments}

This paper is the social science project of the $13^{\text {th }}$ Five-Year Plan of Jilin Provincial Education Department, project No. : 2016089

\section{References}

[1] Yao Wen. Influence of Agriculture Modernization, Population Increase and Trading Policy on the International Competitiveness of Agricultural Products-- Empirical Analysis on the Basis of Cointegration and VEC Model. Economic Survey, 2014,31(2):50-56.

[2] Chen Jiyong, Yao Aiping. Literature Review of the Research on Agricultural Products' International Competitiveness. Commercial Times, 2014(2):49-51.

[3] Zhou Zhengping, Ding Jiayun, Jiang Liuyi, etc. Research on the Agricultural Products' International Competitiveness from the Aspect of Network Marketing. Inquiry into Economic Issues, 2013(3):148-152.

[4] Xue Xuandeng. Empirical Analysis on the International Competitiveness of Agricultural Products of Henan Province. Development and Research, 2012(3):112-114.

[5] Zhou Hao. Analysis on the International Competitiveness of Chinese Agricultural Products Based on Anti-dumping and the Countermeasures. Management Modernization, 2011(6):47-49. 